\title{
Effects of Selected Human Resource (HR) Practices on Nigerian Polytechnics Lecturers' Performances
}

\author{
Suleiman Abubakar Babagana \\ PhD Student \\ Lancashire Business School, \\ University of Central Lancashire, \\ United Kingdom
}

\begin{abstract}
Higher Education (HE) institutions in developing countries have become an area of attention to scholars in the field of Human Resource Management (HRM), particularly, African countries. Polytechnics are one of the higher education institutions (HEIs) in Nigeria, yet, they are not incorporated by scholars in their studies on HEIs, particularly, in Nigeria. This paper presents a study on how polytechnics lecturers perceive how certain Human Resource (HR) practices as recognized by Boselie et al (2005) found to be well observed within a Nigerian Polytechnic impact on their performances and then linking them to lecturer competencies recognized by Robbins et al (2007) and Molefe (2010). Therefore, the research inquires among others essentially; connection between HR practices and perceived performances of lecturers in Nigerian polytechnics. The study employed qualitative research methods in its investigation, engaging semi structured interviews, and then, thematic analysis to analyze data collected. The study revealed that, all the HR practices investigated are well observed in the institution and have impact on the performances of lecturers. Finally, it was established while lecturers wholly embraced the HR practices, they are critical of the reward systems and employees' appraisal practices and therefore need to be enhanced to further improve performances. The main conclusions drawn from this study are; apart from enhancing the some HR practices identified, students should be involved to a certain extent, in appraising lecturers' proficiencies, and also, create an atmosphere for better studentlecturer relations for the attainment of overall organizational objectives.
\end{abstract}

Keywords: HE Institutions, Human Resource Management, HR Practice, Lecturer, Performance

\subsection{Introduction}

\section{Introduction}

Scholars in the field of human resource management (HRM) have conducted a series of studies in this field and one area that received tremendous attention are studies on human resource (HR) practices with significant interest on the relationship between HR practices and performance in higher education institutions (HEIs) in certain developing countries (e.g. Gaertner, and Noller, 1989; Smeenk et al., 2008; Smeenk et al., 2006b; Shattock, 1999; Deem, 1998). To date, there are debates on the connection between organizational commitments with HR practices and how the practices impact on performance (Smeenk et al., 2008), yet, it was found out that, there is exist some differences and similarities in relation to which HR practice has more effect on job performance among countries (Smeenk et al., 2008).

Anakwe (2002) carried out a study in Nigeria on certain HR practices, and thus, reported that; performance appraisal, recruitment and selection, and training and development, seem to be the most observed in organizations. In addition, Olufemi (2009) and Molefe (2010) had conducted studies on HR practices and performance in some universities in Nigeria and South Africa but did not incorporate polytechnics as a component of HEIs, which, for example, constitute about 47 per cent (Education, n.d) of HEIs in Nigeria. The fact that there is little evidence to show how HR practices impact on performance in HEIs in Nigeria, particularly the polytechnics; it is a motivating factor for exploring that area. Even though, previous studies reported that observing a bundle of HR practices could have an effect on organizational performance (Armstrong, 2004), this could not be construed to be relied on, particularly, making reference to polytechnics in Nigeria, unless there is empirical evidence.

The fact that a polytechnic in Nigeria is the center of this study, it will be of paramount importance to highlight their disparity with the universities, even though all are HEIs. Firstly, it is practically impossible for lecturers in the polytechnics to ascend through career progression to professorial positions, irrespective of academic qualifications possessed and researches undertaken. Again, the laws establishing the polytechnics by the government empowers them to only provide training on technical and vocational education, and thus, their focus is providing middle level trained manpower for organizations. Finally, despite the fact that they are HEIs; 
the polytechnics are not empowered to award degrees, even if they have the capacities and resources at their disposal.

\subsection{Significance of the study}

HRM practices play a vital role in the attainment of objectives set by organizations, especially in the service sector (Mathivanan and Nagar, 2013). The HR practices of employee performance appraisal and recruitment and selection are of tremendous relevance in this context, considering the fact that, polytechnics provide training to individuals for organizations explore their expertise by engaging them to run their operations. Despite the fact that scholars reported they found out some similarities and also, dissimilarities, on how certain HR practices have effect on the quality of lecturers in some countries, yet there are evidences of commonalities (see Smeenk et al., 2008; Buckson and Watson, 2002; Shahzad, Bashir and Ramay, 2008; Olufemi, 2009; Ahmad and Shahzad, 2011). Therefore, ensuring that the right type of individuals are recruited at the right times, and subsequently, appraising their performances on the job, ensures the attainment of organisational objectives (Adeyeye, 2008). Ultimately, the management of HEIs, particularly, the polytechnics, lay emphasis on engaging the right calibre of individuals as lecturers, as well as appraising their performances on the job, to be able to achieve the objective of providing competent middle level manpower to organizations is achieved are particularly imperative as reported in previous studies (see Shahzad and Bashir and Ramay, 2008; Guest, 2002; Harley, 2002; Gould-Williams, 2003; Tessema and Soeters, 2006).

\subsection{Objectives of the study}

Consequently, the primary objectives of this paper are; to investigate how lecturers see HR practices impact on their skills, whether or not they link a specific practice to improved performance, the degree to which the three HR practices are observed in polytechnics in Nigeria, and finally, draw conclusions based on the findings made from the study. It is likely that, findings made will fill in the gap as acknowledged by Olufemi (2009), as he suggested that polytechnics or other HEIs apart from universities in Nigeria could be engaged for that purpose.

Thus, other components of the paper are structured as follows; section two delves on reviewing relevant existing literature on the topic and section three discusses on research methodology engaged. Section four presents results and discussions, and finally, the last section deals with conclusion and implications.

\subsection{HRM and Performance}

\section{Literature Review}

Lewin (2007) posit that, HRM encompasses attracting, retaining, utilizing and motivating employees among other things by organizations. Even though, other scholars view it as an essential element to the realization of organizational objectives, since it entails managing resources by engaging people - human resources (Adeyeye, 2008). Thus, Guest (2007) concurring with (Boxall and Purcell, 2000), stressed that, HRM comprises of policies, particularly, making reference to employment, targeted towards maximizing workers' commitment, adjustment and incorporating all aspects of operations in organizations, mainly, employment relations.

Connecting HRM to performance, Boudreau (1991); Jones and Wright (1992), emphasized severally that, the impact of HRM policies and practices on firms' performances tends to be a significant area in the fields of HRM, and other related fields. Consequently, Olufemi (2009) maintained that, the ability to attract, develop and retain vigorous employees, is a vital ingredient necessary towards maintaining and accomplishing organizational objectives. Accordingly, Huselid (1995) emphasized; it is evident that, connection exists between some HRM practices and enhanced performance and thus, some studies have further confirmed that as posited by Adeyeye (2008).

Therefore, three out of the HR practices recognized by Boselie et al. (2005) are being discussed below. Each of these practices incorporates along with them, a variety of activities meant to enhance the competence of employees.

\subsection{HR Practices}

\subsubsection{Contingent Pay and Reward Schemes}

A study conducted by the Chartered Institute of Personnel Development (CIPD) revealed that, a substantial number of firms took into cognizance, their needs while making decisions on the reward policy to engage (CIPD, 2007b). No doubt, the ability to sustain strong and committed employees depends on, among other things, rewards offered and thus, some prior studies (e.g. Fang and Gerhart, 1999) reported connection between pay and intrinsic motivation. Hence, Marchington and Wilkinson (2008) stressed on reward management being an essential element that organizations should give consideration to towards HRM. 
Furthermore, Hendry (1994) concur that, it supports a good payment system that will be motivating and spurring, as a means of employees' financial policy, in attaining the desired output from employees.

Scholars have confirmed reward systems as being a major element of HR practices reported to have an impact on the duo of employees and organizational performances (Caruth and Handlogten, 2001; Lawler, 2000a; Lewis, 2006; Gutherie, 2007) and this, has been confirmed by findings of some prior studies (e.g. Shahzad, Bashir and Ramay, 2008; Frye, 2004).

\subsubsection{Performance Management (including appraisal)}

Pollit (2006) posit that, performance management has been embraced and practiced by a reasonable number of organizations as a HR function. While performance management is continuous, performance appraisal is observed periodically or intermittently, for example; quarterly, semi-annually, annually (Boxall and Purcell, 2007) and thus, Gilmore and Williams (2009), summed up its aims into three major areas which are; communication, development and motivation.

Hence, Mondy, Noe and Premeaux, (2002) emphasized that; the essence of performance appraisal is to support HR managers to be able to successfully carry out HRM functions. In addition, it is likely to enhance employee performance, given that, the aim is to establish the performance and efficiency of employees (Brown and Benson, 2003), that is occasionally conducted (Boxall and Purcell, 2007), which thus, support management in taking decisions related to other HR practices (Mondy, Noe and Premeaux, 2002) since employees know they are being assessed on their jobs.

\subsubsection{Recruitment and Selection}

Taylor and Collins (2000) assert that organizations need to be able to recruit proficient individuals, to be able to achieve organizational objectives, and hence, objectivity should preoccupy the minds of those saddled with this responsibility. Furthermore, Ahmad and Schroeder (2002) posit that, to ensure continuous development of both organizational and employees' performances, there is the need to among other things, the spirit of teamwork among employees is encouraged, through continuous training, in addition to observing other HR practices, which ultimately calls for suitable recruitment and selection procedure in finding prospective employees with these potentialities.

The introduction of new people with new diverse ideas and talents, enhances productivity, and thus, it was found to have significantly influenced on organizational performances (Terpstra and Rozell, 1993; Huselid, 1995; Delaney and Huselid, 1996) and most importantly, in realizing HRM objectives, selection is fundamental (Storey, 2007).

Even though (Boxall and Purcell, 2000; Wright et al, 2001b) posit that, some of the methods used in some previous studies are likely to be challenged, yet, the selection function has been reported to impact on organizations' effectiveness (Terpstra and Rozell, 1993; Delaney and Huselid, 1996; Delery and Dorthy, 1996; Huselid et al, 1997; Madu, Kuei and Lin, 1995).

\subsection{Lecturer Performance in Higher Education: Professional Competencies}

Lecturers plays a vital role in the attainment of the objectives HEIs were established. Ultimately, the individual and collective lecturers' performance is of paramount importance, in the attainment of the objectives for which the various HEIs established are meant to attain. Lecturers' performance is in this context referred to job performance. Shahzad et al. (2011) view job performance as the result of an employee's effort, to carry out a certain $\operatorname{task}(\mathrm{s})$ within a stipulated period, and for this reason, it is pertinent for organizations to be able to attain objectives set, ensure effective management of employees' performances. For instance, Molefe (2010); McCloy, Campel and Cudeck (1994) had reported that, South African HEIs witnessed major modifications, specifically, overhauling their HR practices and policies, so as to develop certain experienced, motivated and expert lecturers thus, exposing lecturers' jobs to quality assessment and performance management as observed by Mapesela and Strydom (2004). Hence, scholars are of the opinion that as a result of that peculiarity associated with lecturers' jobs, their performances is interpreted or appreciated in relation to how proficient they are in their fields, and which is recognized to have conventional benchmarks for success (Arreola, 2000; Spitzer, 2007; White, 2008).

For this study therefore, the universal dimensions of professional competencies as acknowledged by Molefe (2010); Robbins, Odendaal and Roodt (2007) are engaged, which are correspondingly basic lecturer competencies that include; subject mastery, testing (assessment procedures), student-lecturer relations, organizational skills, communication skills, subject relevance and utility of assignments are used. Thus, Williams (2002) postulates that competencies are connected with performance dimensions.

Bearing in mind the center and objectives this study strives to achieve, evidence exist lecturers recognizing some HR practices to have impacted on their performances (Shahzad and Bashir and Ramay, 2008). Despite the fact that HR managers are expected to provide a mechanism for strong HR practices, to sustain lecturers (Molefe, 2010), it is essential that lecturers performances are governed in line with generally 
established professional competencies (Arreola, 2000; Spitzer, 2007; White, 2008) so as to ensure satisfactory performance and quality assessment ((Mapesela and Strydom, 2004) that the lecturers need to be exposed to.

\subsection{Performance Dimensions for Polytechnic Lecturers Jobs}

Prior studies reported the recognition of numerous indices associated with competency-based thinking and linked to positions held by lecturers (Arreola, 2000; Spitzer, 2007; White, 2008). Notwithstanding, as earlier mentioned in previous discussion, seven key lecturer competencies as also acknowledged by Robbins et al (2007); Molefe (2010) is the focus for this study.

Making reference to performance, Molefe (2010) and (Spitzer, 2007) maintain that, observing any significant improvements on performance calls for measuring such improvements, and subsequently, applying the outcome of such measurements which could impact on the duo of the organization and employees. In addition, it also supports goal attainment ahead of performance gaps (Williams, 2002).

It is evident that performance measurement is significantly concerned with effectiveness in respect to how objectives set are achieved by organizations (Molefe, 2010) even though, it has been reported to have positive impact on both organizations and employees, yet, there are debates among scholars on how best to measure performance in public organizations (Andrews, Boyne and Walker, 2011).

\subsubsection{Subject mastery}

The ability for the student to learn and understand is dependent among other things, on the expertise and competence of the lecturer (Analoui, 2007). Hence, it has to be determined if the lecturer has the expertise and skills to teach in a particular subject area. Arreola (2000) observed that, it is not only competence that matters but also, organization, interpretation; adjusting and adapting are necessary elements to induce the learner to comprehend what is imparted. To achieve these therefore, White (2008) suggests that, to enhance teaching and learning, elements such as innovation, incorporation, diffusion and application of knowledge need to be engaged.

Therefore, lecturers' level of competence can be determined by appraising their performances on the job. Mondy, Noe and Premeaux, (2002) and Brown and Benson (2003) stressed that, the rationale behind performance appraisal is to determine the performance and productivity of employees, and will thus, assist management to determine whether or not, a lecturer requires training or retraining to enhance performance (Bartel, 1995; Iddekinge, 2009).

\subsubsection{Testing (assessment procedures)}

This element involves mechanism associated with designing, developing and implementing tools and techniques which is an essential aspect of instructional design (Molefe, 2010). Arreola, (2000) mentioned the following selected elements considered as significant; a test designing plan of the learning objectives, outlining curricula for coursework, handout preparation alongside with additional auxiliary resources, engaging instructional technology; and preparing and enhancing lectures and presentations for the highest instructional impact.

The feedback students receives from their lecturers on the task assessed, assist lecturers in determining whether or not, the desired learning outcomes are attained, which is pertinent in this element (Hill, Lomas and MacGregor, 2003) and for this to be achieved, lecturers need the requisite skills recognized by Arreola (2000). Hence, possessing the requisite skills by lecturers, call for training and retraining programs be organized and conducted for them as posited by Boxall, Purcell and Wright (2007) to be able to perform effectively, despite all challenges associated with the job (Mondy, Noe and Premeaux, 2002).

\subsubsection{Student-lecturer relations}

Student-lecturer relationship has been reported to have contributed on the performance of students, and thus, a cordial relationship enhances better performance outcomes (Arreola, 2000). There is the need to provide a conducive learning atmosphere. Molefe (2010) stressed that, doing this will support and maintain the learning capability of students, and one way of achieving this is by encouraging students to participate actively in all tasks, in all subjects being taught, and by so doing, feedback at the rate which students grasps can be determined (Sinclair and Johnson, 2000). Therefore, for this reason among others, there is the need to appraise lecturers periodically (Heery and Noon, 2008) which is in tandem with the three aims the appraisal strives to achieve which are; communication, development and motivation as observed by Gilmore and Williams (2009) as this could have positive impact on student-lecturer relations.

\subsubsection{Organizational skills}

The organization and execution of tasks by lecturers falls under this dimension. Molefe (2010) also emphasized that, providing needed teaching materials, the organization of lectures, and examination administration and grading among others is one of the skills that should be possessed by lecturers, and thus, 
have impact on the learners' ability to grasp what is expected to be achieved out of the learning outcomes, in line with the institution's rules and regulations, and at the same time, striving to achieve both individual and organizational objectives (Armstrong, 2004) thereby leading to enhanced performance (Wright and McMahan, 1992).

\subsubsection{Communication skills}

This is yet another skill that is significant. Mode of delivery determines to what extent the intended message or context is comprehended. Arreola (2000) posit that, this skill comprises; clarity, getting the attention of the learners and ensuring that the right materials are used, as well as, demonstrating enthusiasms.

Being one of the reasons for employee appraisal, possessing good communication skills can be from the interactions that may arise between lecturers and students, on one hand, and lecturers with their heads on the other. The breakdown of communication could have a severe consequence, as this might affect the objectives of the institution.

\subsubsection{Subject relevance}

Molefe (2010) stressed that this element relates to issues regarding to; making provision for the right instructional materials, making inquiry on modules taught in line with the subject, grading assessments in line with expected learning outcomes, the method of teaching to be engaged and, provision of the list of recommended reference materials with textbooks, among others, are important in this dimension. Thus, this is achievable by keeping abreast with the institutions' and module's objectives, by appraising and reappraising lecturers periodically (Gilmore and Williams, 2009) so as they perform in line with assigned tasks and objectives set to be achieved (Inyang, 2011; Armstrong, 2004).

\subsubsection{Utility of assignments}

Molefe (2010) also emphasized here that, as students are engaged, it is of paramount importance that tasks given to them align with the contents of what is taught, so as to determine if they are grasped and improved their knowledge, and developmental needs. Furthermore, the contents of what is being imparted should reflect the environment and socio-economic life within the living environment of the student (White, 2008) and also, to enhance utility, tasks should align with learning objectives motivating and challenging to students (Layman, Williams and Slaten, 2007). Hence, the right caliber of people should be considered for engagement as lecturers (Taylor and Collins, 2000), while engaging coaching and mentoring as training techniques for new recruits (Mondy, Noe and Premeaux, 2002), to be able to achieve the desired outcomes (Wright and McMahan, 1992; Jones and Wright, 1992; Huselid, 1995).

\section{Methodology}

The method to engage for any study is reliant on the objective(s) the study seeks to achieve and thus, this study engages the qualitative research methods. This method is trustworthy and authentic (Guba and Lincoln, 1994) as well as flexible (Mason, 2002a) which makes it possible for unforeseen problems that may come up be addressed during the research process (Lewis, 2003). Furthermore, this method aligns to my ontological and epistemological position making reference to the world view I may possess as opined by Denzin and Lincoln (1994) and will thus, offer meta-analytical foundation to rely upon conducting my study (Ponterotto, 2005).

Acknowledging the positions of Cohen and Manion (1995) and; Ghauri and Gronhaug (2002), a case study technique was employed for this study, to investigate the topic, as little or nothing is known about what is investigated in the institution used for the study. The choice of this technique is in tandem with the position of Yin (1984) being only three out of other HR practices that are relevant for the attainment of the objectives the institution was established to achieve are being investigated.

Feedback from interviews conducted were transcribed to reduce the quantum of data, and thereafter, grouped into main themes. Subsequently, recognizing the position of Coffey and Atkinson (1996), analysis of data was done thematically, by using the data grouped into categories, bearing in mind the literature reviewed, and the objectives this study seeks to achieve, by matching the data earlier categorized, to make and report findings to be able to draw conclusions.

\section{Results And Discussions}

As stated in previous discussions in the preceding sections of this paper, researchers have established that some HR practices have often been observed in organizations and have impacted on them (Smeenk et al., 2004; Teseema and Soeters, 2006; Boselie et al., 2005; Carlson, Upton and Seaman, 2006; Shahzad, Bashir and Ramay, 2008; Ahmad and Shahzad, 2011; Inyang, 2011) though, some have submitted that it has no impact (Olufemi, 2009). Precisely, it was found out in a study in Pakistani universities, that there is a positive 
connection between a certain set of HR practices on lecturers' perceived performances, however, performance evaluation practices are not connected to employee perceived performance (Shahzad, Bashir and Ramay, 2008). Also, Molefe's (2010) study revealed that 'subject mastery' and 'research undertaken' among others, are essential in determining lecturers' performances. However, a study undertaken by Olufemi (2009) revealed that there is no relationship between the usage of HRM best practices and size of universities in Nigeria. Nonetheless, Huselid, Jackson and Schuler (1997) posit that, there exist indications of the presence of a bundle of HR practices that impact on the performance of organizations.

At the study site, participants acknowledged certain HR practices perceived to be observed in the institution. They revealed that employee performance appraisal, contingent and performance related rewards, recruitment and selection, training and developing involving coaching and mentoring, promotion, and discipline, are well observed in the institution.

This was confirmed by a principal officer in the institution in the registry, and further stated that, the all three of the key HR practices being investigated are observed in the institution, and further testified that they impact on perceived performances of lecturers as reported in some studies (Shahzad, Bashir and Ramay, 2008; Ahmad and Shahzad, 2011). Lecturers upheld that HR practices being observed are in accordance with the best HR practices to their knowledge. Specifically, they recognized that these practices have provided for a good the working atmosphere to operate [Fieldwork interview, 2012].

Firstly, it is established that, organizations motivate their employees by rewarding them (Fang and Gerhert, 1999), with a good compensation plan, and this, it was observed, sustains and improves their performances (Shahzad, Bashir and Ramay, 2008).

Participants for this study posited and stressed that, being a public institution; the reward system is determined by the government. It was however found out that, lecturers are not happy with the disparity in pay with their colleagues in the universities, even though, all are in the HEIs. Caruth and Handlogten (2001) recognized that, performance is connected to remuneration, and this concurs with the positions of Shahzad et al. (2008) where they averred that; poor compensation practices leads to fall in lecturers' performances, but this seems to be the major concern of the lecturers in their responses during the interview. This concern was further confirmed by a principal officer in the registry, ascribing it to the conditions of service and the salary structure drawn by the government as the proprietors of these institutions. Ultimately, participants indicated that at any given opportunity, lecturers in the polytechnic opt for the universities because of these disparities.

Secondly, Gilmore and Williams (2009) observed that, there has been a tremendous increase in the use of HR practice of performance appraisal in organizations owing the relevance linked to it, which makes it possible for HR managers decide whether or not, employees require some support to be able to achieve organizational targets based on their performances (Heery and Noon, 2008).

Participants for this study were unanimous in their responses. They posit that, there is an established performance appraisal method used by management to appraise lecturers' performances (Field interview, 2012) and further confirmed that it is done annually; at the beginning of every year to assess the performance of the preceding year, and this is in tandem with the observation of Boxall and Purcell (2007). In addition, it was also confirmed from the registry of the institution that, appraisal reports generated, are used to take decisions by management on staff promotion, among other things, and those found to meet up with the requirements, are promoted and thus, this motivates lecturers as reflecting improved performance as observed by Brown and Benson (2003). Again, concurring with the positions of Ahmad and Shahzad (2011), lecturers confirmed the appraisal as being able to pin point to the management employees' strengths, weakness and areas of needs, to be able to enhance their performances, and accomplish organizational objectives. Even though, lecturers were critical regarding the techniques used in the appraisal as it lacks objectivity, there was no indication that the management was considering reviewing the appraisal procedure (Field interview, 2012). Precisely, lecturers indicated great concern where appraisal is done by only one person, and thus, could be biased in reporting and is one of those issues that Redman and Wilkinson (2009) raised and observed as lack of objectivity and manipulation of the appraisal exercise, which could have consequence on both the employees, and the organization. Most importantly, it was observed that outcomes of appraisal were never discussed with employees (lecturers).

It was also found out that, both the lecturers and HR managers in the polytechnic were against students partaking in appraising lecturers' performances. They opined that, students, particularly the weak ones, could be biased in their appraisal, which will thus, affect the outcome of the exercise and eventually, be a set back to the aim sought to be achieved. Nonetheless, study participants agreed that, students have a significant role to play in appraisal lecturers, since they have frequent direct contacts and interactions with them, and hence, in a good position to report on lecturers' performances, more especially, relating to competencies.

Probing on what constitute the appraisal, competencies of lecturers and areas determined, the respondents for this study, differed in their responses. Though, most of the participants concurred that personality traits, productivity, subject mastery, assessment procedure, communication skills and, subject relevance are areas 
assessed during the appraisal; very few of the respondents indicated organizational skills, student-lecturer relations and, utility of assignment as areas part of the appraisal, even though, important competencies as observed by Robbins et al. (2007) and also, what Molefe (2010) referred to as, important descriptors of lecturers' behavior, bearing in mind, the nature of lecturers' job. That notwithstanding, participants were unanimous that, employee appraisal has connection with their performances, which Teseema and Soeters (2006) also recognized.

Finally, positing with Paauwe and Richardson's (1997) model, conclusion can be drawn that, effective recruitment and selection is connected with employee satisfaction, motivation and commitment, and thus, leading to enhanced productivity.

Making reference to other HR practices investigated in this study, recruitment and selection is the most acknowledged by all respondents. Participants opined that, there exist a well laid down recruitment and selection procedure, which as they claim, to be in line with the best HR practices, devoid of intricacies associated with it while carrying out the exercise, and this accounts for the institution's ability to engage competent hands as lecturers, which is in tandem with the position of Huselid (1995).

As recognized by Ahmad and Schroeder (2002), recruitment and selection is intended to source prospective employees that can fit into the yearnings and aspirations of the organization. Participants further confirmed that, this HR practice is well observed and free of bias by the HR managers, and this, they linked to the desire by the institution to achieve the objectives for which it was established.

Acknowledging how this HR practice is observed in the polytechnic signifies satisfaction from the side of the lecturers. Most importantly, the internal recruitment policy of the institution is applauded as whenever vacancies exist, efforts are made to fill them up internally, except where there are no qualified individuals found from within, and this, the lecturers recognize as motivating. Employees' satisfaction has been acknowledged as not only improving employees' productivity but also, organizational performances (Madu, Kuei and Lin, 1995). Generally, from the responses gathered on this HR practice from the participants, there has been no inadequacy associated with it brought up.

\section{Conclusion}

This concluding section delves on the study's reflections, followed by its implications, and then finally, suggested areas for further study.

\subsection{Reflections}

The focal concern of this study was to ascertain whether or not, certain HR practices have effects on polytechnic lecturers' performances in a polytechnic in Nigeria. Hence, three out of the HR practices recognized by Boselie et al (2005) which are; contingent pay and reward schemes, performance appraisal, and recruitment and selection were studied. Furthermore, the impact of the three practices studied linked with seven lecturers' competencies recognized by Molefe (2010) comprising subject mastery, testing (assessment procedures), and student-lecturer relations, organizational skills, communication skills, subject relevance and utility of assignments were likewise discussed

An overview of the HRM area was given, focusing especially on the HR practices recognized by Boselie et al. (2005). In reviewing the literature, contributions made by researchers in this area, on the premise of their understanding, and previous studies carried out, were engaged. Boselie et al. (2005); and Wright and McMahan (1992) affirmed that, combinations of certain HR practices has been found to yield organizational effectiveness and better performances results, and thus, Huselid (1995) further emphasized that organizations that embrace, and bundle HR practices, benefit from economic contributions of improving their performances and also enhanced employees' observed performances (Shahzad, Bashir and Ramay, 2008).

\subsection{Implications}

The study this paper is presenting was able to find out how certain HR practices impacted on lecturers' performances in a particular polytechnic, used as case study in Nigeria. Therefore, the outcome of this study is anticipated to bring to fore light to decision makers in HEIs, particularly the polytechnics and also, the government being the proprietor of public HEIs, the perceptions lecturers have on the impact HR practices have on their performances. It is further expected that, decision makers will address some areas observed that require attention based on the findings of this study, by improving on them, engaging appropriate HR strategies, in line with the best practices, to achieve organizational objectives.

There is the need for decision makers in HEIs, particularly the government, to take a look at the issue of compensation, with reference to remuneration, which has been raised by polytechnics lecturers', with a view to attaining the objectives for which these institutions were established.

The management of the polytechnic should consider reviewing the employees' appraisal technique being used, so as it will be all embracing. Incorporating students in lecturers' appraisal will afford the 
management to ascertain the level of competence of lecturers in subject areas, and for these to be achieved; students are in a better position to do that. However, heads of departments, being the supervisors of the activities of lecturers, should be encouraged by management to discuss outcomes of appraisals with lecturers after every appraisal period, so that, areas of concern could be addressed, and thus, making the final outcome of the appraisal more objective.

Organizational skills, student-lecturer relations and, utility of assignment among other things, should be incorporated to form part of the appraisal and thus, making the appraisal system all embracing.

Recruitment and selection policy of the institution is commendable, and hence, management should sustain it to be able to maintain its reputation in this regard, for the attainment of the overall objective of the institution.

Overall, considering the outcomes of this study, the institution is on the right track, making reference to the objectives for which it was established. Management should strive to engage lecturers periodically, to inculcate the spirit of participatory management, and also, encourage student-lecturer relationship, thus, leading to effective relationship management which entails ability to direct (Shahzad et al., 2011; Spencer and Spencer, 1993).

\subsection{Further Research}

Despite the fact that a series of studies were conducted on areas related to this study, specifically on organizational (e.g Huselid, 1995; Delaney and Huselid, 1996; Pfeffer and Veiga, 1999) and employees performances (e.g Gould-Williams, 2003; Wright et al., 2003; Tessema and Soeters, 2006) still, there is the need for further research, particularly, in the developing nations (e.g Shahzad, Bashir and Ramay, 2008; Ahmad and Shazad, 2011). Only three aspects of HR practices as recognized by Boselie et al., (2005) were investigated by this study along with seven performance dimensions linked with lecturers' job recognized by Molefe (2010). All these could be studied in detail for example; wholly studying an element of the HR practices.

Another interesting area for research could be, a comparative study using the same topic of this study, looking at public and private polytechnics which thus, might be interesting because, the proprietorship differ.

Finally, engaging ethnography for a study with the above suggested areas or other areas not mentioned, could also report interesting findings.

\section{Journal Papers:}

\section{References}

[1]. K.N.Gaertner and S.D Nollen, Career experiences, perceptions of employment practices, and psychological commitment to the organization, Human Relations 42: 1989, 975-991.

[2]. S. Smeenk, C. Teelken, R. Eisinga, and H. Doorewaard, An international comparison of the effects of HRM practices and organizational commitment on quality of job performances among European university employees, Higher Education Policy, 21: $2008,323-344$.

[3]. S. G. A. Smeenk, R. A. Eisinga, J. C. Teelken, and J. A. C. M. Doorewaard, The effects of HRM practices and antecedents on organizational commitment among university employees, International Journal of Human Resource Management 17: 2006b, 20352054.

[4]. M. Shattock, Governance and management in universities: the way we live now, Journal of Education Policy, 14: 1999, $271-282$.

[5]. R. Deem, New managerialism and higher education: the management of performances and cultures in universities in the United Kingdom. International Studies in Sociology of Education 8: 1998, 47-70.

[6]. U. Anakwe, Human resource management practices in Nigeria: challenges and insights. International Journal of Human Resource Management, 3(7), 2002, 1042-59.

[7]. A. J. Olufemi, An evaluation of human resource management (HRM) Practices in Nigerian universities: The impact of size, The Social Sciences, 4: 2009, 494-498.

[8]. G. N. Molefe, Performance measurement dimensions for lecturers at selected universities: An International perspective, South Africa Journal of Human Resource Management, 8 (1), 2010

[9]. B. Mathivanan, and M. G. R. Nagar, A study on HRM practices in public sector banks in krishnagiri district, Journal of Dental and Medical Sciences (Iosr-Jdms), 12 (4), 2013, 1-14.

[10]. J. M. Buck, and J. L. Watson, Retaining staff employees: the relationship between human resources management strategies and organizational commitment. Innovative Higher Education 26: 2002, 175-193.

[11]. K. Shahzad, S. Bashir, and M. I. Ramay, Impact of HR practices on perceived performance of university teachers in Pakistan, International Review of Business Research Papers. 4 (2), 2008, 302-315.

[12]. S. Ahmad, and K. Shahzad, HRM and employee performance: A case of university teachers of Azad Jammu and Kashmir (AJK) in Pakistan), African Journal of Business Management, 5(13), 2011, 5249-5253.

[13]. D. E. Guest, Human resource management, corporate performance and employee wellbeing: Building the worker into HRM, Journal of Industrial Relations, 44 (3), 2002, 335.

[14]. B. Harley, Employee responses to high performance work system practices: an analysis of the AWIRS95 data, Journal of Industrial Relations, 44(3), 2002, 418-434.

[15]. J. Gould-Williams, The importance of HR practices and workplace trust in achieving superior performance: A study of public sector organizations, International Journal of Human Resource Management, 14:1, 2003, 28-54.

[16]. M. Tessema, and J. Soeters, Challenges and prospects of HRM in developing countries: Testing the HRM-performance link in eritrean civil service. International Journal of Human Resource Management, 17 (1), 2006, 86-105.

[17]. P. Boxall, and J. Purcell, Strategic human resource management: where have we come from and where should we be going? International Journal of Management Reviews, 2(2), 2000, 183-203. 
[18]. M. A. Huselid, The impact of human resource practices on turnover, productivity and corporate financial performance. Academy of Management Journal, 38 (3), 1995, 635-672.

[19]. P. Boselie, G. Dietz, and C. Boon, Commonalities and contradictions in HRM and performance research, Human Resource Management Journal, 15(3), 2005, 67-94.

[20]. M. B. Frye, Equity based compensation for employees: Firm performance and determinants. Journal of Financial Resources, 27(1), 2004, 31-54.

[21]. C. Pollit, Performance management in practice: a comparative study of executive agencies. Journal of Public Administration Research and Theory, 16 (1), 2006, 32-35.

[22]. M. Brown, and J. Benson, Rated to exhaustion? Reaction to performance appraisal processes, Industrial Relations Journal, 34(1), 2003, 67-81.

[23]. S. Ahmad, and R. G. Schroeder, The importance of recruitment and selection process for sustainability of total quality management, International Journal of Quality and Reliability Management, 19(5), 2002, 540 - 550.

[24]. D. E. Terpstra, and E. J. Rozell, The relationship of staff practices to organizational level measures of performance, Personnel psychology, 46, 1993, 27-48.

[25]. J. T. Delaney, and M. A. Huselid, The impact of human resource management on perceptions of organizational performance, Academy of Management Journal, 39, 1996, 949-69.

[26]. J. E. Delery, and D. H. Doty, Modes of theorizing in strategic human resource management: Tests of universalistic, contingency and configurational performance predictions. Academy of Management Journal, 39:4, 1996, 802-83.5

[27]. M. A. Huselid, S. E. Jackson and R. S. Schuler, Technical strategic human resource management effectiveness as determinants of firm performance, Academy of Management Journal, 40: 1997, 171 -188.

[28]. C. N. Madu, C. N. Kuei, and C. Lin, A comparative analysis of quality practice in manufacturing firms in the U.S. and Taiwan, Decision Sciences, 26 (5), 1995, 621-635.

[29]. K. Shahzad, M. Sarmad, M. Abbas, and M. A. Khan, Impact of emotional intelligence (EI) on employee's performance in telecom sector of Pakistan, African journal of business management, 5 (4), 2011, 1225-1231.

[30]. R. A. McCloy, J. P. Campbell, and R. Cudeck A confirmatory test of a model of performance determinants, Journal of Applied Psychology, 79 (4), 1994, 493-505.

[31]. R. Andrews, G. Boyne, and R. M. Walker, The impact of management on administrative and survey measures of organizational performance, Public Management Review, 13(2), 2011, 227-255.

[32]. A. P. Bartel, Training, wage growth and job performance: Evidence from a company database. Journal of Labor Economics, 13(3), $1995,401-425$.

[33]. C. V. Iddekinge, Effects of selection and training on unit-level performance over time: a latent growth modeling approach, Journal of Applied Psychology, 94 (4), 2009, $829-843$.

[34]. L. Hill, L. Lomas, and J. Macgregor, Students' perceptions of quality in higher education. Quality Assurance in Education, 11(1), 2003, 15-20.

[35]. B. J. Inyang, Creating value through people: Best human resource (HR) practices in Nigeria, International Business and Management, 2 (1), 2011, 41-150.

[36]. P. M. Wright, and G. C. McMahan, Theoretical perspectives for strategic human resource management. Journal of management, 18 (2), 1992, 295-320.

[37]. J. G. Ponterotto, Qualitative research in counseling psychology: A primer on research paradigms and philosophy of science, Journal of Counseling Psychology, 52 (2), 2005, 126-136.

[38]. S. G. A. Smeenk, J. C. Teelken, and J. A. C. Doorewaard, 'Academici en managerialisme. Een onmogelijke combinatie? Organisatiebetrokkenheid van academici bij de 'nieuwe' universiteit', Tijdschrift Voor Hoger Onderwijs 22: 2004, 86-95.

[39]. D. S. Carlson, N. Upton, and S. Seaman, The impact of human resource practices and compensation design on performance: an analysis of family-owned SMEs, Journal of Small Business Management, 44(4), 2006, 531-543.

[40]. J. Paauwe, and R. Richardson, Introduction special issue on HRM and Performance. The International Journal of Human Resource Management, 8: 1997, 257-262.

[41]. J. Pfeffer, and J. F. Veiga, Putting people first for organizational success, Academy of Management Executive 13 (2), $1999,37-48$.

\section{Books:}

[42]. F. Analoui, Strategic Human Resource Management, London: Thomson Learning, 2007.

[43]. M. Armstrong, A Handbook of Human Resource Management Practice, $9^{\text {th }}$ edn, Kogan publishers, India, 2004.

[44]. R. A. Arreola, Developing a Comprehensive Faculty Evaluation System, Bolton, MA: Anker publishing company, Inc., 2000.

[45]. D. L. Caruth, and G. D. Handlogten, Managing compensation (and understanding it too): A Handbook for the Perplexed, Westport, CT: Green wood Publishing Group, 2001.

[46]. Chartered Institute of Personnel Development, Factsheet: Working Hours in the UK, London, CIPD, $2007 \mathrm{~b}$.

[47]. L. Cohen, and L. Manion, Research Methods in Education, London: Routledge, 1995.

[48]. N. K. Denzin, and Y. S. Lincoln, Ed. Handbook of Qualitative Research. Thousand Oaks, CA: Sage publications, 1994.

[49]. P. Ghauri, and K. Grønhaug, Research Methods in Business Studies: A Practical Guide, Prentice Hall. Financial Times, 2002.

[50]. S. Gilmore, and S. Williams, Human Resource Management, Oxford, Oxford University Press, 2009.

[51]. E. G. Guba, and Y. S. Lincoln, Competing Paradigms in Qualitative Research, in N. K. Denzin \& Y. S. Lincoln (eds.), Handbook of Qualitative Research (pp. 105-117). Thousand Oaks, CA: Sage, 1994.

[52]. E. Heery, and M. Noon, A Dictionary of Human Resource Management, Oxford University Press Inc., New York. 2008.

[53]. C. Hendry, HRM: A Strategic Approach to Employment, London, Butterworth. 1994.

[54]. E. Lawler, Rewarding Excellence, San Francisco: Jossey-Bass, 2000a.

[55]. L. Layman, L. Williams, and K. Slaten, Note self: Make Assignment Meaningful, Computer Science Education, North Carolina State University: Raleigh, N.C, USA, 2007.

[56]. M. Marchington, and A. Wilkilson, Human Resource Management at Work: People Management and Development, $4^{\text {th }}$ ed. CIPD, 2008.

[57]. J. Mason, Qualitative Researching, 2nd edition. London: Sage Publications, 2002a.

[58]. R. S. Williams, Managing Employee Performance - Design and Implementation in Organizations. Australia: Thompson Learning, 2002.

[59]. R. W. Mondy, R. M. Noe, and S. R. Premeaux, Human Resource Management, 8th ed., Upper Saddle River, NJ: Pearson PrenticeHall, 2002.

[60]. T. Redman, and A. Wilkinson, Human Resource Management: Text and Cases, $3^{\text {rd }}$ ed., prentice Hall/Financial Times, 2009. 
[61]. S. P. Robbins, A. Odendaal, and G. Roodt, Organisational Behaviour - Global and South African Perspective. South Africa: Pearson Education, 2007.

[62]. D. R. Spitzer, Transforming Performance Measurement: Rethinking the Way we Measure and Drive Organizational Success. New York: Amacom, 2007.

\section{Chapters in Books:}

[63]. J. W. Boudreau, Utility Analysis for Decisions in Human Resource Management, in Marvin D. Dunnette \& Leatta M. Hough (eds.), Handbook of Industrial and Organizational Psychology, 2nd ed., vol. 2. Palo Alto: Consulting Psychologists Press, pp. 621-745,

[64]. P. Boxall, J. Purcell, and P. Wright, The Oxford Handbook of Human Resource Management (ed.). Oxford Press, 2007.

[65]. D. L. Caruth, and G. D. Handlogten, Managing Compensation (and understanding it too): A Handbook for the Perplexed, Westport, CT: Green wood Publishing Group, 2001.

[66]. D. E. Guest, HRM and the Worker: Towards a New Psychological Contract, in Boxall P., Purcell J. and Wright P. (eds) The Oxford Handbook of Human Resource Management. Oxford: Oxford University Press, 128-146, 2007.

[67]. J. Gutherie, Remuneration Pay Effects and Work, in Boxall P., Purcell J. and Wright P. (eds) the Oxford Handbook of Human Resource Management. Oxford: Oxford University Press, 2007.

[68]. G. R. Jones, and P. M. Wright, An Economic Approach to Conceptualizing the Utility of Human Resource Management Practices, in K Rowland \& G. Ferris (eds.), Research in Personnel and Human Resources Management, 10, 271-299. Greenwich. GT: Jai press. 1992.

[69]. D. Lewin, HRM in the $21^{\text {st }}$ Century, in C. Wankel (ed.), Handbook of $21^{\text {st }}$ Century Management, London: Sage, 2007.

[70]. P. Lewis, 'Reward Management' in T. Redman and A. Wilkinson (eds), Contemporary Human Resource Management, $2^{\text {nd }}$ edition, London, Financial Times/Pearson, 2006.

[71]. M. S. Taylor, and C. J. Collins, 'Organizational Recruitment: Enhancing the Intersection of Theory and Practice' in C. L. Cooper and E. A. Locke (eds), Industrial and Organizational Psychology: Linking Theory and Practice, Oxford: Blackwell, pp.304-34, 2000 .

\section{Proceedings Papers:}

[72]. F. Adeyeye, Globalization and the challenges of human resource management in africa. Proceedings of the 9th Annual Conference of the International Academy of African Business and Development (ACIAABD’08), University of Florida, Gainesville, USA, 2008 .

[73]. M. Fang, and B. Gerhart, How Do Company Differences in Pay for Performance Strategy influence Intrinsic Motivation and Overall Motivation? Paper presented at Annual Meeting of the Academy of Management, Chicago, 1999.

[74]. M. L. E. Mapesela, and F. Strydom, Performance Management of Academic Staff in South African Higher Education System: A Developmental Project, Presented at the OECD Conference on Trends in the Management of Human Resources in Higher Education, University of Free State, Bloemfontein. 2004.

\section{Website}

[75]. Education, nd. US Diplomatic Mission in Nigeria, Directory of Polytechnics and Colleges in Nigeria. Available at: http://nigeria.usembassy.gov/nigeria polycolleges.html [Accessed 24th august 2012].

\section{Newspaper/Magazine}

[76]. A. White, Managing Academic Performance: Understanding Development in the academic Environment. Guardian News and Media Limited, pp. 1-29, 15, April, 2008. 